\title{
РЕЦЕНЗИИ
}

\section{Dreams about the Black Sea}

\author{
V.E. Vozgrin, A. A.Petrova, V.A. Ushakov
}

For citation: Vozgrin V.E., Petrova A. A., Ushakov V. A. Dreams about the Black Sea. Vestnik of Saint Petersburg University. History, 2018, vol. 63, issue 4, pp. 1317-1328. https://doi.org/10.21638/11701/ spbu02.2018.419

The review of the book by the English researcher Neal Ascherson "Black Sea. The Birthplace of Civilization and Barbarism" (2017) analyzes the contribution made by the author to the study of the Black Sea basin and, mainly, the ethnic, political and cultural history of the tribes and peoples of the Black Sea since the deep antiquity to the present day. To successfully solve the task, N. Ascherson chose the genre of travel writing supplemented by insights into the historical past of the region. A comprehensive comparative approach to the work has revealed that N. Ascherson achieved his goal, but did not manage to avoid a number of serious mistakes. Some of them are caused by the author's insufficient knowledge of the subject of study and the realities of the Black Sea region. Other errors stem from N. Ascherson's biased approach to assessing the role of historical figures and entire ethnic groups in the events and phenomena related to the history of the Black Sea region. For example, he fails to consider the biggest drama in the modern history of the Black Sea region - the deportation of the Crimean Tatars in 1944. The heroic pages of the defense of Novorossiysk and Sevastopol from the German and Romanian aggressors are also poorly reflected. Virtually nothing is said about the modern

Valerii E. Vozgrin - Doctor in History, Professor, St. Petersburg State University, 7-9, Universitetskaya nab., St. Petersburg, 199034, Russian Federation; v.vozgrin@spbu.ru

Валерий Евгеньевич Возгрин - д-р ист. наук, проф., Санкт-Петербургский государственный университет, Российская Федерация, 199034, Санкт-Петербург, Университетская наб., 7-9; v.vozgrin@spbu.ru

Ariadna A. Petrova - PhD in History, Associate Professor, St. Petersburg State University, 7-9, Universitetskaya nab., St. Petersburg, 199034, Russian Federation; a.petrova@spbu.ru

Ариадна Александровна Петрова - канд. ист. наук, доц., Санкт-Петербургский государственный университет, Российская Федерация, 199034, Санкт-Петербург, Университетская наб., 7-9; a.petrova@spbu.ru

Vladimir A. Ushakov - Doctor in History, Professor, Saint-Petersburg State University, 7-9, Universitetskaya nab., St. Petersburg, 199034, Russian Federation; v.ushakov@spbu.ru

Владимир Александрович Ушаков - д-р ист. наук, проф., Санкт-Петербургский государственный университет, Российская Федерация, 199034, Санкт-Петербург, Университетская наб., 7-9, v.ushakov@spbu.ru

(c) Санкт-Петербургский государственный университет, 2018 
history of the region. The reviewers have made major comments, which, perhaps, will help readers to avoid mistakes in their own perception of the historical past and the present-day reality of the region.

Keywords: Black Sea, Hinterland, Scythians, Goths, Crimean Tatars, Abkhazians, Turks.

\section{Сны о Черном море}

\section{B. Е. Возгрин, А. А. Петрова, В. А. Уиаков}

Для цитирования: Vozgrin V.E., Petrova A. A., Ushakov V. A. Dreams about the Black Sea // Вестник Санкт-Петербургского университета. История. 2018. Т. 63. Вып. 4. С. 1317-1328. https://doi. org/10.21638/11701/spbu02.2018.419

В рецензии на книгу английского исследователя Н. Ашерсона «Черное море. Колыбель цивилизации и варварства» (2017) анализируется вклад, который автор внес в изучение бассейна Черного моря, главным образом в изучение этнической, политической и культурной истории племен и народов Причерноморья с глубокой древности до наших дней. Для успешного решения поставленной задачи Н. Ашерсон избрал жанр путевых записок, обогащенных экскурсами в историческое прошлое региона. Комплексный сравнительный подход к работе Н. Ашерсона показал, что автор достиг заявленной им цели и создал энциклопедически подробный и поистине всеохватывающий труд, достойный называться памятником Причерноморью и его людям. При всем этом, однако, ему не удалось избежать ряда тяжелых ошибок. Часть из них вызвана слабым знакомством с предметом изучения и реалиями местной действительности. Это касается наименований различных видов рыб Чёрного моря и разновидностей прибрежной флоры, а также традиций и древних обычаев многонационального местного населения. Второй комплекс ошибок имеет своим источником предвзятый подход Н.Ашерсона к оценке роли исторических личностей и целых этнических групп в событиях и явлениях, связанных с историей Причерноморья. Так, им совершенно не отмечена крупнейшая драма в новейшей истории Причерноморского региона - депортация крымских татар в 1944 г., слабо отражены героические страницы обороны Новороссийска и Севастополя от германских и румынских агрессоров. Практически ничего не сказано и о новейшей истории региона - не только Северного Причерноморья, но и морского побережья на всей его протяженности. Рецензентами сделаны принципиальные замечания, которые, возможно, помогут читателям избежать ошибок в собственных представлениях об историческом прошлом и актуальной действительности региона.

Ключевые слова: Черное море, хинтерланд, скифы, готы, крымские татары, абхазы, турки.

The shores of the Black Sea have been a border between Europe and Asia for millennia. Here, the Greek settlers met the Scythian nomads; this place was also a boundary between "barbarism" and "civilization". Therefore, a unique mixture of peoples and tribes developed in a natural way on the sea coasts and the adjacent hinterland.

The sea in general strongly influenced the features of the natural landscape as well as emerging urban environment and the economic development of nearby villages; it ensured human survival by a variety of ways and means, or, on the contrary, made human life extremely complicated. Probably, it is for this reason that the seas have been have been deified since olden times; have inspired models for developing life philosophy of entire nations, and laid foundation for the emerging ethnic and political identity. 
All of the above fully applies to the Black Sea, which although being called "Hospitable" by the Hellenes, was treated by them, somewhat condescendingly, as some kind of a gulf within their native and familiar Mediterranean region. The correction of this olden unfairness, along with the assertion of the unique value of Pontus Euxine, constitute laudable features of the book by Neil Ascherson", "the most original, talented and elegant work about the Black Sea, known in the world historiography of the last century" ${ }^{2}$ - according to one of the book's first reviewers in Germany.

The preference given by the historian to the Black Sea world, far from his native Scotland, is not accidental. He was no stranger to maritime romance - his father was an officer of the Royal Navy, and the author himself served a considerable time in the Marine Corps. But young Neal Ascherson spent much more time in the lecture halls of the glorious Eton where he was taught history by the world-famous Eric Hobsbawm. Actually, the master admitted later: "Ascherson was perhaps the most brilliant student I've ever taught. But in fact, I did not instruct him too much. I just let him on free flotation". Neal owed the specific interest to the Black Sea to his father, a participant of evacuation of Denikin's troops from Novorossiysk by British ships, who told the boy a lot about distant southern harbours.

Having preferred a hard life as a journalist to that of a scholar, the graduate of Eaton and Cambridge soon became known in the press as a major specialist in Russia. The disintegration of USSR and the dramatic events in the south of the former empire prompted him to undertake a large-scale work. "At last 160 million people now living in the Black Sea basin - that is to say, in the area drained by rivers which run into the Sea" are to become a subject of that work ${ }^{3}$. To meet this objective, N. Ascherson preferred a genre of historical and cultural essay, enabling to explain the present by the past in a simple and unconstrained form, appealing to a diverse range of readers. Thus, the book has not become a historical scholarly work in the ordinary sense of the word; it rather represents a traveller's diary for the most part - a successful mix of fiction and historiography.

This is demonstrated by the manner of presentation chosen by N. Ascherson. Like a pendulum constantly swinging between the past and the present, it unfolds a Big story at the backdrop of a number of unremarkable, private life paths of the Black Sea people that "seem more fantastic than the fairytales of the "Thousand and One Nights" ", according to an English reviewer. At the same time, the author plainly intersperses established facts with impressions and fiction. Thus, the author does not expound the chronological history of the Black Sea or the Black Sea Coastal Area, but, jumping from epoch to epoch, continually weaves new insights into the narrative, which enables him to look into the past or predict the inevitable future from the depths of time.

Such composition obviously suits the subject matter - a mixture of tribes and peoples which used to live on the shores of the warm sea for centuries - since the settlements around the Black Sea actually represented a mosaic of innumerable ethnoses that had formed a complex and subtle "geological" structure. However, as the author clarifies his metaphor, "a geologist would not call this process simple sedimentation, as if each new influx of settlers neatly overlaid the previous culture. Instead, the heat of history has melted

\footnotetext{
${ }^{1}$ Asherson N. Chernoe more. Kolybel' tsivilizatsii i varvarstva / transl. by V. Babitskaia. Moscow, 2017.

2 Verheyen G. Das Schwarze Meer // Ostmitteleuropa. 1997. 47 Jahrgang. Hft 3. P. 208.

3 Asherson N. Chernoe more... P. 414.

${ }^{4}$ Ascherson N. Black Sea: The Birthplace of Civilisation and Barbarism. Folio, 1995.
} 
and folded peoples into one another's crevices, in unpredictable outcrops and striations. Every town and village is seamed with fault-lines. Every district displays a different veining of Greek and Turkic, Slav and Iranian, Caucasian and Kartvelian, Jewish and Armenian and Baltic and Germanic"5.

Every reader, opening $\mathrm{N}$. Ascherson's book, immediately feels the value of new knowledge about the nationalities - of something familiar, though not always with a guaranteed accuracy of the information, for instance, about the Scythians, whose way of life was described in detail by Herodotus. By the way, this ancient Greek historian was not deemed credible for a long time; then the situation began to change, but remained the same with the reading public. And Neil Ascherson was probably the first to address the general public with the revised opinion of Herodotus: "For the extraordinary quality of Herodotus is that his information grows in importance from year to year, as archeology confirms it"'. And, in proof of this he refers to a Herodotus' description of a Scythian custom to arrange a steam bath after a lavish burial of a leader. A tub of boiling water is the principal feature: hemp seeds are thrown into it - with the understandable purpose; following which the participants "howl in their joy. And as late as in the 1950s, a bag of cannabis was found in one of the excavated graves in Altai settlement Pazyryk located thousands of miles from the Black Sea Coastal Area, on the periphery of the Scythian world. The Herodotus' rightness had to wait two and a half millennia to be confirmed N. Ascherson notes bitterly ${ }^{7}$.

The book also abounds in other information about the Black Sea "barbarians", first described by the Athenian intellectuals of the fifth century BC, and later by the Western historians - about the Sarmatians, Khazars, Kipchaks-Cumans, the Golden Horde people, who would capture the South Russian steppe in the coming centuries, the Crimean Goths, Karaites that settled not only in the Crimea, but also in Poland and Lithuania. Or about the Pontic Greeks residing in Asia Minor since the ancient times, who were expelled by the Turkish Kemalists after the First World War, and settled much further to the south, on the Peloponnese Peninsula and in mainland Greece.

Thus, the book tells primarily about the Black Sea Coastal Area, its cultural space impregnated with history. However, the sea itself attracts the writer's attention - its shape and depth, the in-flowing waters, the ecological situation. The author's speculations about the sulphurous layer of the water, spelling a disaster of a global scale, menacing not only the Black Sea Coastal Area, sounds quite justifiable ${ }^{8}$. But even describing the shores and their inhabitants, Ascherson constantly uses "marine" metaphors, thus marrying the sea and coastal space. And still, notwithstanding the title of the book, it is not primarily the sea that is the focus of the author's studies, since his thoughts constantly return to other things: the problems arising from the close proximity of different nations, religions and cultures.

Traveling along the Northern Black Sea Coastal Area, N. Ascherson could not help noticing a strange phenomenon of our time: the Cossacks (Kozakdom) that unexpectedly appeared in the last decades. The scholar stresses that they "appeared", not "revived" - he came to this veritable conclusion, treating this sensitive problem with delicate seriousness.

\footnotetext{
5 Asherson N. Chernoe more... P. 391.

6 Ibid. P. 137.

7 Ibid. P. 138.

8 Ibid. P. 28-30.
} 
For that, he had to examine the causes ot theirpost-war emergence, one of which should be sought in the Crimea: "The Cossack revival is a disaster of the human ecology. Not all the ecological catastrophes of the Black Sea happen in water. Just as the inrush of pollutants into the Black Sea has decimated the variety of marine species, allowing certain algae and the marauding jellyfish $\langle\ldots\rangle$ to multiply on an explosive scale, so Stalin's deportations created a social void, a monstrous demographic impoverishment into which the Cossack movement now expands uncontrollably"'.

There is almost no pure rivulet of harmonious existence in this stream filled with blood and suffering: "To feel oneself a Cossack is to enter an excruciating crisis of identity" 10 . A remarkably deep observation. It is to "feel", not "to be", because one can be a Cossack only by blood, having glorious steppe knights as ancestors - which the modern mummers cannot boast of at all. Therefore, the first thought coming to mind is that of the red-letter day for "Cossacks" of the Crimea, where no Cossacks have lived from time immemorial. So the "crisis of identity" is in fact inevitable as any second-year history student can publicly condemn you of imposture. And on the same page N.Ascherson reveals the essence of his observation: the Cossacks and the like suffer two delusional psychic syndromes. "One is false consciousness: a skewed and paranoid awareness of the exterior world" composed entirely of hostile forces. "The second syndrome is dominance. The "outposter" must constantly remind himself of who he is by displaying his power over "others". These "others" are held to be inherently inferior as individuals, usually because of their race or religion".

And it does not matter that identity crisis arises in this ongoing process: the Cossacks differentiating themselves from the "domiciled" Russians, while "considering themselves distinct from "settled" Russians and, at the same time, appointed carriers of the essential Russian values - display that syndrome with gloomy intensity. A Russian is somebody who subdues non-Russian" ${ }^{11}$. But "how can this defense of the Russianness be at the same time the defense of Cossacks who separate themselves from the Russians?" Here, the Cossack muddle about identity solidifies into a dead-end of contradiction"12.

However, what in evident to N. Ascherson, seems not to be a matter of concern for a Cossack who follows the ancestors' fictional covenants with primal bluntness. This is not a metaphor: another western visitor of the Don Area, taking a close look at the inner world and the behavioural model of a typical Cossack, compared them with a horse in the same arguable manner. The Cossack sincerely believes that everything can be appropriated with impunity: "He does not miss the opportunity to take advantage of the occasion - similar to a horse that does not restrain its appetite when passing by a cartful of hay. Thus, both of them, Kalmyks and Cossacks, cannot abandon this manner, that is, leave their neighbours in peace - Tatars, Crimeans"13.

Moving from place to place, N. Ascherson talked a lot with the Cossacks. And he could not but finish the analysis of their problems by a conclusion worthy of the professional historian of Eton level: "Compared with the Indo-Iranian peoples of Antiquity and some Turkic nations that followed them, the Cossacks were at a primitive stage of development.
9 Ibid. P. 178.
10 Ibid. P. 171.
11 Ibid. 173.
12 Ibid. P. 174.
${ }^{13}$ Haven P. von. Puteshestvie v Rossiyu / transl. by V.E. Vozgrin. St. Petersburg, 2007. P. 55. 
Strength, race and masculinity are infrequently the values of a stable and traditional society - these are rather the values of bandits"14.

Thus, the author is far from drawing an idyllic picture of coexistence of the Black Sea tribes and peoples. Of course, Greeks and Turks, Russians and Ukrainians, Adzhars and Tatars, Georgians and Abkhazians peacefully lived for centuries side by side. Just next to each other, side by side, and only in rare cases they co-existed in the midst of joint everyday life. And a small spark from the outside (particularly brought by the north wind) was sufficient to ruin life in a peaceful propinquity, when indifference and reciprocal nonchalance turned into rejection and even hatred.

In the context of the collapse of the USSR, the change of regimes in Eastern Europe and the outbreak of hostilities in the Northern Black Sea Coastal Area, the book has been of a considerable political relevance. And it is not by chance that its author brings to the memory of his multilingual readers that in the XIV century, it was right from here, the Black Sea Coastal Area, that the black death spread to the whole of Europe, killing one third of the population of the continent ${ }^{15}$. N. Ascherson, using this excursus to the past, makes the present more definite and clear once again, warning Europe against the threatening development of events in its eastern part.

But, frightened by the prospect of a catastrophe, and rightly considering national or ideological strife as its source, he evades the truth, taking the opposite direction, not only denying the right of peoples and nations to claim ancestral homeland, but also doubting the legitimacy of these concepts as such, by arguing that any ethnic commonality is based on a year-dot myth of co-origination. There are no witnesses to this prehistoric event, still the later history of cumulative procession through the centuries and millennia does not add anything to the truth in this sense - it is semi-mythical. "Even the portrait of a common cultural tradition, as evidence of ethnic identity, all too often dissolves away at the first application of rigorous fact".

In his description, it is the indigenous peoples who come in for the blame, and among them - the Crimeans for some reason, as there were "no natives, no aboriginals" on the Crimean peninsula: "Before the Scythians, before the Cimmerians who preceded them or the Bronze Age populations, who raised the first burial-mounds, there were human beings who had come from somewhere else". However, the Scythians and all other incomers, felt uncomfortable here for some reason: they "eventually dispersed or moved further" 16 . And the simple truth that the Crimea is a truly promised land which no one abandoned by their own will, and from where no one got "scattered", did not come to N. Ascherson' mind. This is despite the fact that no information has been preserved about the completely depopulated peninsula, although the ancient (and contemporary) historians would have certainly noted such an incredible event. Here the author sets out an old theory, according to which, all tribes and peoples were guests in their historical homeland, all of them had inevitably come from somewhere. According to this theory, the only real indigenous peoples can be found perhaps only in Africa, from where the whole human race seems to have emerged.

It is not difficult to understand that such reasoning, depriving indigenous peoples of the right to their historical homeland, not only is anti-human, but also contradicts the

14 Asherson N. Chernoe more... P. 185.

15 Ibid. P. 164-165.

16 Ibid. P. 57. 
international acts on indigenous peoples ${ }^{17}$ that declare the urge to protect their rights in the post-colonial period from the encroachments of former oppressors. But instead of taking this indisputable fact into account, the historian suggests that readers should tell the Crimean Tatars who returned home from the exile "that their burning conviction of homeland and ethnic identity was false, as well as their belief that their homeland is here. And you could support that with some evidence. You might remind them that the Tatars of the Golden Horde had exchanged their own Mongolian language for the Turkic spoken by the local Kipchaks, that they abandoned shamanism for Islam, that they have interbred continuously with Turks and Russians and that - like the Greeks, and for the same tragic reason of deportation, «the land of their birth" is usually not Crimea but Kazakhstan or Uzbekistan"18. Here, one textual period contains several absurd statements, so we have to deal with all of them separately.

Even if the Golden Horde people "had exchanged their own Mongolian language for the Turkic", this does not deprive them of the right to remain culturally and anthropologically what they were before, similarly to Peruvian or Mexican aborigines who have preserved their Indian blood and in many ways - the culture, despite their Spanish speech. The same can be said about Mongols' accepting Islam. But the main misconception of the author concerns his absolute conviction, not demanding any proof, that the origin of present-day Crimean Tatars is derived from so-called Tatar-Mongols.

In fact, the population of the Golden Horde was anthropologically composed of Mongols who, by the time of invading the Crimea, spoke Turkic, having adopted the language of Cumans conquered by them. The same language became state/administrative for the Crimean Khanate that was formed in the $15^{\text {th }}$ century, and further - for the multilingual population of the Crimea. As far as the "continuous interbreeding" is concerned, it certainly took place; the question is - in what proportion and with whom. The fact is that by the time of Mongols' coming to the Crimea, it was densely populated by various tribes and nations of the Caucasian (Europid) anthropological type (Greeks, Goths, Venetians, Genoese, Turks, etc. - in total, about 30 ethnic groups). Each of them had its own well-developed culture, and it was the time of their natural merging into a higher-order substance - a new civilization resembling the Euro-Atlantic type, but still different - the Black Sea civilization. However, this process was artificially interrupted through annexation of the Khanate by Russia, therefore it came to a halt somewhere at the level of "semi-civilization" - this conclusion was made by F. Braudel in respect to the high culture of Crimean Tatars ${ }^{19}$.

And numerically these incomers exceeded the Mongolian administration and the army to such anextent that they virtually merged with the local population within several

17 The author means UN ILO "Convention Concerning the Protection of Indigenous and Other Fribal and Semi-Tribal Populations in Independent Countries" of 1957 No. 107. The further consolidation of positions of this concept in the international law took place after the revision of 1957 Convention, when the new Convention adopted in 1989 already referred to "indigenous peoples". In accordance with these conventions, indigenous peoples are understood as nations that lived on their lands before the invasion of migrants from other regions, in the case of the Crimea - the people who lived on the peninsula before the Mongol conquest, who borrowed the Turkic language from the newcomers, and nowadays are known as Crimean Tatars.

18 Asherson N. Chernoe more... P. 439.

19 Brodel' F. Material'naia tsivilizatsiia, ekonomika i kapitalizm, XV-XVIII vv. Vol.1. Struktury povsednevnosti: vozmozhnoe i nevozmozhnoe. Moscow, 2007. P. 71. 
centuries; this process being guite natural: "The barbarian triumphs only for a short-term period. Before long it is devoured by the conquered civilization" ${ }^{20}$. The above applies to the external appearance of the Crimean Tatars, a relatively new nation for Europe. They vast majority of them are Caucasians. Strangely enough, N. Ascherson, did not notice that after visiting the peninsula several times, but, nevertheless, he traced the genetic line of the Crimean aboriginal inhabitants directly to the Mongols of the Horde.

As for the Crimean Tatars' "native" land being Uzbekistan or Kazakhstan, as mentioned by him, there was not a single year since the deportation when they were not willing to leave that land and return home. The same is characteristic of young people born in Asia, but retaining love for the Crimea.

And, finally, let us dwell on N. Ascherson' statement that "their (i. e. the Crimean Tatars. - Authors' note) burning conviction of homeland and ethnic identity was false". This statement is totally ungrounded, which is inexcusable for a professional historian. The same concerns his inconsistency: denying the mere notion of "indigenous peoples", and the reality of its bearers, he forgot his assertions made literally two years after the publication of the book with respect to the issue of inter-ethnic relations of his fellowmen - the Scots. Already in 1997, the scholar took an active part in their national movement ${ }^{21}$, later devoting to them his first monograph on indigenous peoples "Stone Voices"22. In 1999, he was even elected to the Scottish parliament for his merits in the movement, although later he acknowledged the truth in an interview: "Scotland is mongrel nation anyway. The Scots have never pretended to be an ethnically homogeneous mass"23.

N.Ascherson's typological error in his text about Goths is not so important: This "proto-Germanic confederation of peoples from southern Scandinavia occupied Crimea in the third century AD"24. Even the earlier predecessors of Goths in the Baltic region (with a difference of 45 centuries), namely Cumbrians and Teutons, were called by ancient authors and by later scholars not "proto-", but just Germans, that is, a fully ripe nation with its own language and religion ${ }^{25}$. And the Ostrogoths, by the way, came to the Crimea not from Southern Scandinavia, but from their old villages in the Vistula estuary, as has long been proven.

The author is at odds with the truth, talking about the fate of another indigenous nation of the Crimea, the Karaites (Karaim), claiming that they avoided "serving to any government" 26 . On the contrary, Karaites, recognized as excellent warriors, were willingly hired for military service by almost all neighboring rulers. And in view of their phenomenal honesty, they were entrusted the highest financial positions by the same sovereigns, including the Crimean khans. Even in modern times, and even in the $20^{\text {th }}$ century, having a Karaite as a chief accountant was considered to be a sign of quality for any firm or bank. In another place the author asserts that Chufut-Qale Karaites looked after "the old synagogue" 27 , which is a grave offence to them. They church is called kenesa,

\footnotetext{
20 Ibid. P. 63.

21 Wroe N. Romantic Nationalist // The Guardian. 2003. 12 April.

22 Ascherson N. Stone Voices. The Search for Scotland. London, 2002.

23 Wroe N. Romantic Nationalist...

24 Asherson N. Chernoe more... S. 58.

${ }^{25}$ Lund A. A. Die Ersten Germanen. Ethnizität und Ethnogenese. Heidelberg, 1998. Passim.

${ }^{26}$ Asherson N. Chernoe more... P. 54.

27 Ibid. P. 55-56.
} 
unlike the place of worship of the Jewish rabbis, with whom the Karaites have a very cold relationship, to put it mildly.

In the context of one of the numerous topics that complement the main theme, the author covers the history of Polish Sarmatizm, rightly characterizing it as one of main reasons of the decline and division of the kingdom. However, he is mistaken believing that this strange ideology "possessed the old Polish aristocracy"28. The situation was much worse. Firstly, Sarmatzm was the second religion for the entire multitudinous Polish gentry, including the poorest layers (the latter comprising $10 \%$ of the population). Secondly, Poland, because of this pseudo-nomadic fake obsession, was the only Baltic country that had no fleet or even political allies. Therefore, when the time to split the country came, if found itself alone in the face of the crowned bandits - and vanished.

Another dubious statement of the author is the following: "The nationalist political Cafer Seidament and the Lithuanian-Tatar General Sulkiewicz had organized a Moslem corps to support the German armies in Crimea" ${ }^{29}$. Here one sentence contains three inaccuracies. To begin with, the $1^{\text {st }}$ Moslem corps was formed not in the Crimea and not for the Crimea.

In July 1917, Lieutenant-General of the Imperial Army M. A. Sulkiewicz headed off to the south, as instructed by the Provisional Government, where he proceeded to form Muslim corps from the units of the $1^{\text {st }}$ Romanian Front (hence the title " 1 st"!). The command of the corps included several Polish Tatars; the remaining staff was mixed as well. Later, the Military Council of the Provisional Government ordered that the corps should be relocated to the Crimea, but the peninsula was occupied by the Germans at the time, which prevented the corps from entering it with the weapons. However, after the March offensive of the Austro-Hungarian army, the corps was nevertheless disarmed by the Austrians near Tiraspol. M. Sulkiewicz himself arrived in the Crimea with a group of officers, where he started, with the support of the Germans, setting up the Crimean territorial government; soon he took on leadership of it and became Minister of internal and military affairs. In autumn of the same year, the government headed by M. Sulkiewicz resigned, passing the power to a new cabinet headed by Solomon Krym.

C. Seydahment was Minister of Defence and Minister of Foreign Affairs of the Crimean People's Republic (December 1917 - January 1918), subsequently - Minister of Foreign Affairs in M.Sulkiewicz's government (spring 1918autumn 1818), and he took no part in the alleged formation of military units in the Crimea.

As to the armed forces of all these governments in the aggregate, the formation of a new Muslim corps there was out of question. According to P. Wrangel's recollections, they had just "a handful of armed units: the Crimean dragoon regiment quartered at the garrisons of Simferopol, Bachchisarai and Yalta, staffed with Crimean Tatars, several officer squadrons, two field batteries, as it seems"30. That was all.

Another statement of the same informative quality concerns a later period: “...Within days of the Soviet reconquest in April 1944, whole villages had been executed and dead Tatars swung from the Simferopol lamp-posts"31. However, not only Crimean Tatars were hung on the poles near the Old marketplace; and so to the first "fact" - it never

\footnotetext{
28 Ibid. P. 10.

${ }^{29}$ Ibid. P. 65.

30 Wrangel P. N. Zapiski. Noyabr' 1916 - Noyabr' 1920. Vol. I. Minsk, 2003. P. 76.

31 Asherson N. Chernoe more... S. 68.
} 
took place. Nevertheless, this fake has already been spread - so far in the reviews of the book $^{32}$, but, after all, the reviews have a general reader. One more inaccuracy of the book relates to the similar subject: "The Crimean Tatars were the first ethnic minority to suffer total deportation" 33 . If the author means the peninsula, then the Crimean Tatars were not the first in the deportation programme: the local German colonists were indiscriminately deported three years earlier (1941). If we bear in mind Stalin's deportation acts in general, the first of them (in the Baltic countries and "annexed" part of Poland) took place even earlier - before the war ${ }^{34}$.

The author claims, relying on some mystical sources, that only after the XX congress of the Communist Party of the Soviet Union "the first timid petitions arrived in Moscow from Tashkent"35. This is not true, the national protest movement began only in 1956, which is far otherwise. Practically from the very first years of exile, the deported Crimeans distributed leaflets demanding return of their nation to its historical homeland, and the number of those who made attempts to escape from special settlements and were mercilessly sentenced for that counted thousands - it was also before 1956.

"Geographic paradoxes" of the book should be separately mentioned Taman peninsula, as stated by the author of the book, is "a long spit of Asia" 36 . But in fact, the peninsula is not long, but rather has an angular-roundish shape - unlike Tuzla and Chushka spits extending from it, which are really elongated and slender. Not to mention that this place belongs not to Asia, but to Europe.

And more on geography: "the newly built port of Novorossiysk" 37 could not have been founded by Catherine II (as the author of the book writes). The territory of the future city (Tsemez bay with a fortress Sujuk-Qale) was passed to Russia only in 1829, according to the Treaty of Adrianople. The author merely confused the seaport, Novorossiysk, with the older city of the same name on the river Dnieper- which is pardonable, given the difficult fate of the second toponym. In 1776, a city Ekaterinoslav was laid on the site of the settlement of Polovitsy in Zaporozhie - a major city that has changed its name several times. From 1796 to 1802 its name was Novorossiysk, then again Ekaterinoslav, from 1926 to 2016 - Dnepropetrovsk, and now it is called Dnipro.

Further, on page 51, the author places Eski Qirim (the present Old Crimea) not on the ancient route of Feodosiya-Karasubazar, in the midst of the peninsula, but somewhere on the shore of the Azov Sea. And, he continues, once leaving it, "the Tatars moved to Bakhchisarai and set up the palace of the independent khanate". The thing is that no Bakhchisarai existed at the time they left Eski Qirim, and they "moved" approximately in 1440 to a fortress Kyrk-Er (modern Chufut-Qale), which became the first capital of the Khanate. And only in 1532, almost a century later, a new residence of the khan, called Bakhchisarai, was built (in Crimean Tatar language - "Palace in the Garden"), around which the future city of the same name began to develop.

And - as a quite unnecessary reproach to the author of the book - a few remarks about what he could have written, but for some reason preferred not to do. Well, he narrates

32 Braumd D. Understanding the Euxine: Near Ascherson's Black Sea // Arion: A Journal of Humanities and the Classics. Third Ser. 1998. Vol. 6, N 1. P.122-123.

33 Asherson N. Chernoe more... P. 69.

34 Vozgrin V.E. Istoriia krymskikh tatar. In 4 vol. Vol.4. Simferopol', 2013. P. 13-15, 153-316.

35 Asherson N. Chernoe more... P.69.

36 Ibid. P. 150.

37 Ibid. P. 224. 
about the 1812 epidemic of plaque in Odessa in great detail, mentioning even the leather clothing of convicts assigned to remove the corpses ${ }^{38}$. But he does not say a word about where the bodies were taken, missing an opportunity to mention a unique monument to those terrible years that originated spontaneously. This is a man-made hill Chumka, to the right of Vodoprovodnaya street, which has survived to the present day, with a plague cemetery hidden beneath layers of urban rubbish.

The sketch about the residences of Prince M. Vorontsov, Governor-General of Novorossiysk region ${ }^{39}$ is lacking in two little-known nuances. His magnificent palace in Odessa housed a Naval Department of Odessa Committee for State Security in the 1950s-1960s. - a subject of scary stories. And an old villa of Duc de Richelieu in Alupka, casually mentioned, was purchased by the Prince at little to no cost because of its deplorable state (intended as a site for the most famous of his palaces). The thing is that the villa was built on the coast without any consideration of the Black Sea squalls, with huge windows that were regularly squeezed out by the wind, so eventually Duc gave it up as hopeless and stopped repairing it.

In addition to this, when we read an extensive quote from the old English pilot chart, given in the book, containing a recommendation to enter Kamysh-Burun Bay closer to $\mathrm{Kerch}^{40}$, we get impressed by the endurable character of not so much the hydrographic situation as the navigation signs. They have not changed much over the past century and a half - unlike the subwater world. The war made its corrections, which should have been reflected on the same pages of the book. We read in the Russian pilot chart: "There are several sunken ships in the bay". And further: "Some sunken wrecks $\langle\ldots\rangle$ lie in the immediate vicinity of Kerch-Yeñi Qale navigation canal, therefore special care must be taken when navigating in the area" 41 .

Further, a number of pages are devoted to Chersonese ${ }^{42}$, but not a word is mentioned regarding the largest "archaeological" crime in the history of science connected with it. This early-medieval city with ancient quarters in the central part had survived to the Modern Time, retaining its walls. However, immediately after the annexation of the Khanate, it was literally dismantled to stones: a naval base of Sevastopol was being constructed in the neighboring Tatar Ak-Yar (Ahtiar) where this "building material" was sent. And so far one can find stones with Chersonese petroglyphs in the walls of the south-side old houses.

Now let us add some remarks about the flora and fauna of the Black Sea. For instance, a fish "turbot", which is unknown in the Black Sea, is mentioned in the book ${ }^{43}$. One can guess that the author meant one of the varieties of flatfish. The author of the book describes "wild olives: tiny, white and delicious to chew" [meaning green olives, in Russian translation] on page 346. This is, judging by the description, a plant with sweet, though astringent, fruit called "[black] olives" in the south, but by no means "[green] olives". And one more disappointing error: the famous Tristia (Sadness) by O. Mandel'shtam is given a senseless title of Trisita, which is hardly a misprint - the remainder of the text is corrected irreproachably.
38 Ibid. P. 232.
39 Ibid. P. 239.
40 Ibid. P. 347.
${ }^{41}$ Lotsiia Chiornogo moria. Leningrad, 1976. P. 452-453.
42 Asherson N. Chernoe more... P. 42, 48,83 etc.
43 Ibid. P. 433. 
In conclusion, some more considerations of general character. N. Ascherson's book, since the year of its publication and nearly to our days, has not been deprived of attention of reviewers from the countries where it was published in English or in translation. All of these newspaper or magazine annotations and reviews are exceptionally positive, even laudatory in nature - a rare case for the media of different political and ideological trends - especially given plenty of reasons for criticizism of the work. It will just suffice to mention the author' statement regarding the "true homeland" of the Crimean Tatars located far to the east, in Uzbekistan or Kazakhstan. Here N.Ascherson, willingly or unwillingly, echoes the most spiteful fabrications of political ideologists of the 1950s, ready to produce any forgery and slander against the Crimean Tatars, just to prevent their return to the peninsula, which they had reserved for themselves.

But such fabrications seem not to have been heard since those old years, so the author of the book probably drew such conclusions on his own. Through these are just misguided guesses, the title "Dreams" is not accidental. Indeed, it seems that N. Ascherson, enamored with the Black Sea, often dreams of it. And if we continue our guesses, these dreams are of ambivalent nature. Some of them are serene memories of the green water of the sea, the "bluest in the world", of Odessa and Bakhchisarai, of captivating nights and exuberant sunrises, as they are seen in Yalta. And the author, taking his pen, creates the lines about the sea and its people, magnificent in their accuracy and unsophisticated romanticism. But none of us is sheltered from dreams of a completely different kind, which are cast not by blessed angels, but by a well-known character with a tail and horns. And then, awakening from heavy nightmares, the unhappy mortal cannot refrain from gloomy prophecies for the future and from unfounded criticism of the characters of the distant past - remember the dark bookish images of M. A. Sulkiewicz and D. Seydahmet who are to blame solely for their unconditional love for the Crimea.

It remains to be said that this prolonged review was brought to life by an excusable desire to set off the invariably laudatory reviews with a sole unflattering response. It was fundamentally indispensable in order to create an objective opinion about N. Ascherson's monograph - it has deserved it.

\section{References}

Ascherson N. Black Sea: The Birthplace of Civilisation and Barbarism. London, Folio Publ., 1995, 305 p. Asherson N. Chernoe more. Kolybel' tsivilizatsii i varvarstva. Transl. by V. Babitskaia. Moscow, AST Publ.; Corpus Publ., 2017, 480 p. (In Russian)

Ascherson N. Stone Voices. The Search for Scotland. London, Granta Books Publ., 2002, 240 p.

Braumd D. Understanding the Euxine: Neal Ascherson's Black Sea. Arion: A Journal of Humanities and the Classics. Third Series, 1998, vol. 6, no. 1, pp. 118-123.

Brodel' F. Material'naia tsivilizatsiia, ekonomika i kapitalizm, XV-XVIII vv. Vol. 1: Struktury povsednevnosti: vozmozhnoe i nevozmozhnoe. Moscow, Ves' Mir Publ., 2007, 592 p. (In Russian)

Khaven P. fon. Puteshestvie v Rossiyu / Per. s datskogo, vstuplenie, kommentarii i primechaniya V. E. Vozgrina. St. Peterburg, Vsemirnaia literature Publ., 2007, 528 p. (In Russian)

Lund A.A. Die ersten Germanen. Ethnizität und Ethnogenese. Heidelberg, C. Winter Publ., 1998, Passim, $181 \mathrm{~S}$.

Verheyen G. Das Schwarze Meer. Ostmitteleuropa. 1997, 47 Jahrgang, Hft. 3, S. 208.

Vozgrin V.E. Istoriia krymskikh tatar. In 4 vol. Vol. 4. Simferopol', Tezis Publ., 2013, 620 p. (In Russian)

Wrangel P.N. Notes. November 1916 - November 1920. Vol. I. Chapter I. Minsk, Kharvestb Publ., 2003, 480 p. (In Russian) 